\title{
Mental development in congenital hypothyroidism after neonatal screening
}

\author{
R ILlIG, ${ }^{*}$ R H LARGO, ${ }^{*}$ Q QIN, ${ }^{*}$ T TORRESANI, ${ }^{*}$ P ROCHICCIOLI, $\dagger$ AND A LARSSON $\ddagger$ \\ ${ }^{*}$ Department of Paediatrics, University of Zurich, Switzerland, †Service de Pédiatrie Centre Hospitalier \\ Universitaire, Toulouse, France, and $\ddagger$ Department of Pediatrics, University Hospital, Uppsala, Sweden
}

In 1961 at the International Congress of Mental Retardation in Vienna the late Henning Andersen, one of the founder members of the European Society for Paediatric Endocrinology (ESPE), emphasised the importance of early treatment of children with congenital hypothyroidism and hoped that methods would soon be available to allow the diagnosis to be made soon after birth. ${ }^{1}$ At the annual meeting of ESPE in 1974 Pierre Rochiccioli $^{2}$ was the first in Europe to report such a method, and in 1978 and 1979 reports on national ${ }^{3-5}$ and regional neonatal screening programmes ${ }^{6-8}$ for diagnosing congenital hypothyroidism were presented. These activities prompted the ESPE to start collaborative studies on congenital hypothyroidism.

A working party was established consisting of three ESPE members assisted by experts in the special problems to be studied. To facilitate international collaboration one representative from each country was appointed. The tasks of the working party comprised making recommendations on technical problems, organising follow up of patients, writing regular progress reports, and carrying out collaborative studies. Information was exchanged by letters, questionnaires, and progress reports sent to all members of ESPE and others participating in neonatal thyroid screening.

This paper gives the results of a collaborative study on mental development in children with congenital hypothyroidism diagnosed by neonatal thyroid screening ${ }^{9}$ and the latest progress report on how screening programmes are being developed in Europe.

Children with congenital hypothyroidism are heterogeneous with regard to various factors that may influence mental development. Some are related to congenital hypothyroidism-for example, athyroidism, ectopic thyroid gland, dyshormonogenesis, prenatal onset of hypothyroidism, and age at start of treatment-while others are not-for example, complications of pregnancy and delivery, associated disorders, congenital malformations, and the socioeconomic state of the family.

As a result of the collaboration of paediatricians and psychologists from 14 European countries we were able to analyse the importance of some of these factors in the mental development of a large number of children with congenital hypothyroidism. Two questionnaires were sent out: one asked for data on individual children with congenital hypothyroidism, the other concerned the reference or control values for the respective developmental and intelligence tests used in the different centres.

Initially we planned to express the results of developmental and intelligence tests (DQ, IQ) as a standard deviation score, a method that would have enabled us to pool results of different tests and age groups. Unfortunately, this plan had to be abandoned because the relevant reference values necessary were not available or did not represent unselected population samples. The results are therefore expressed as absolute figures for age and test methods separately. Statistical analyses were carried out with the Mann-Whitney and Kruskal-Wallis tests.

\section{Results}

A total of 928 questionnaires on children with congenital hypothyroidism were obtained; 138 could not be analysed, however, because answers were incomplete or sample numbers per test were too small for statistical evaluation, or both. The following analysis is therefore based on data on 790 children who underwent a total of 1590 tests. Table 1 shows the aetiology of the congenital hypothyroidism and the age of the children at the start of treatment. There were 571 girls and 216 boys; the sex of three of the children was not specified. One hundred and forty seven had had complications during pregnancy or delivery, and 71 had associated 
Table 1 Aetiology of congenital hypothyroidism and ages at start of treatment

\begin{tabular}{lc|ll}
\hline Aetiology & $\begin{array}{l}\text { No of } \\
\text { children }\end{array}$ & $\begin{array}{l}\text { Age at start } \\
\text { of treatment } \\
\text { (days) }\end{array}$ & $\begin{array}{l}\text { No of } \\
\text { children }\end{array}$ \\
\hline Athyroidism & 221 & $1-15$ & 212 \\
Ectopic thyroid & 343 & $16-30$ & 333 \\
Dyshormonogenesis & 81 & $31-45$ & 146 \\
Other & 20 & $46-60$ & 40 \\
Unknown & 125 & $61-90$ & 27 \\
& & 91 and over & 18 \\
\hline
\end{tabular}

illnesses or malformations. The socioeconomic state of the family as judged by paternal occupation and maternal education was high in 172 , middle in 394 , and low in 162; in 62 it was not known. In 46 children socioemotional conditions were considered to be inadequate.

The screening programme was successful in that thyroid substitution was initiated in 545 infants $(69 \%)$ before the age of 1 month. In the remaining children, however, treatment was delayed, sometimes for more than 90 days, which is unacceptable for a neonatal screening programme unless treatment was postponed intentionally: in some newborn infants with raised serum concentrations of thyroid stimulating hormone, concentrations of thyroxine were normal in the beginning. Repeated estimations at intervals of two weeks showed, however, a decline in thyroxine concentration and a rise in thyroid stimulating hormone concentration, indicating the necessity for thyroxine replacement, usually at the age of 2-4 months.
Table 2 shows the results of the developmental and intelligence tests applied at different ages. They are all generally accepted methods of evaluating mental development in infants and children. The numbers tested decreased with age because neonatal thyroid screening was introduced only during recent years. For the same reason the number of children tested in many of the participating centres over the age of 5 years was relatively small for statistical evaluation.

Fig 1 is a summary of DQ and IQ results grouped according to age and test methods. In an attempt to show the influence of risk factors and associated findings on mental development simultaneously, the results are given as means (SD) in four columns showing the total number of children with congenital hypothyroidism, the number with additional risk factors, the number with associated diseases or malformations, and the number without other findings. Mean DQ and IQ scores were within the normal ranges in most age and test groups. Risk factors and other diseases were associated with lower mean scores. Conversely, children without risk factors or other diseases tended to have higher mean scores. This pattern was seen in most age groups and test methods with sufficient sample sizes.

Interestingly DQ and IQ scores obtained with different test methods at certain ages showed large variations. As these tests were carried out in various centres we do not know whether the variations are due to different handling of the test methods or differences in the populations tested, or are inherent in the test methods themselves. This merits further study.

The influence of the socioeconomic state of the

Table 2 Methods of testing development and intelligence in 790 children at different ages

\begin{tabular}{|c|c|c|c|c|c|c|c|c|c|c|}
\hline \multirow[t]{2}{*}{ Method } & \multicolumn{9}{|c|}{ Age at testing (years) } & \multirow{2}{*}{$\begin{array}{l}\text { Total } \\
\text { No }\end{array}$} \\
\hline & 6 months & 1 & $11 / 2$ & 2 & 3 & 4 & 5 & 6 & 7 & \\
\hline Brunet-Lezine & 99 & 253 & 75 & 162 & 64 & 15 & 4 & & & 672 \\
\hline Griffiths & 64 & 152 & 70 & 95 & 66 & 42 & 16 & & & 505 \\
\hline Bailey & & 26 & 19 & 118 & 10 & & & & & 173 \\
\hline Stanford-Binet & & & & 2 & 30 & 15 & 10 & 1 & 1 & 59 \\
\hline Terman-Merrill & & & & 18 & 12 & 26 & 2 & & & 58 \\
\hline Snijders-Oomen & & & & & & 31 & & 1 & & 32 \\
\hline WPPSI & & & & & & 1 & 23 & 1 & & 25 \\
\hline WISC & & & & & & & & 14 & 3 & 17 \\
\hline Kramer & & & & & 4 & 8 & & 4 & & 16 \\
\hline HAWIVA & & & & & & & & 2 & 13 & 15 \\
\hline Gesell & & 7 & 2 & & 1 & & & & & 10) \\
\hline NEMI & & & & & & & 5 & 3 & & 8 \\
\hline Total & 163 & 438 & 166 & 395 & 187 & 138 & 60 & 26 & 17 & 1590 \\
\hline
\end{tabular}

WPPSI $=$ Wechsler preschool and primary scale of intelligence; WISC $=$ Wechsler intelligence scale for children; HAWIVA=German version of WPPSI; NEMI $=$ Nouvelle echelle métrique de l'intelligence. 

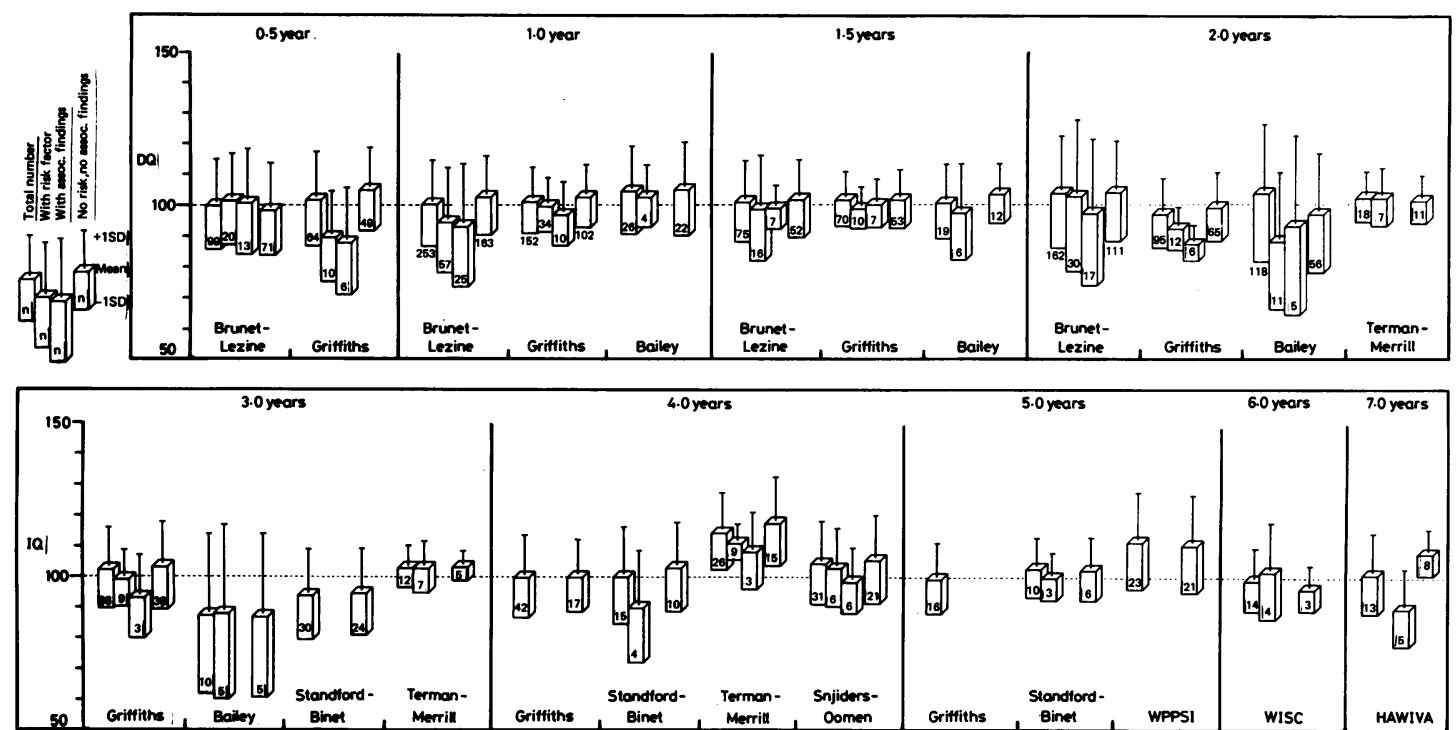

Fig 1 Developmental and intelligence quotients in 790 children with congenital hypothyroidism. Results are grouped according to age and test methods.

family, classified as high, middle, and low, was tested by the Kruskal-Wallis analysis of variance. Table 3 shows that differences between the three classes were not (or weakly) significant in infants up to 1 year of age. There was, however, a significant increase in impact on mental development with increasing age.

Among the factors directly related to congenital

Table 3 Influence of socioeconomic state of family on mental development

\begin{tabular}{|c|c|c|c|}
\hline $\begin{array}{l}\text { Age } \\
\text { (years) }\end{array}$ & Test method & $\mathrm{No}^{*}$ & $\begin{array}{l}\text { Analysis of } \\
\text { variance ( } p \text { value) }\end{array}$ \\
\hline 6 months & $\begin{array}{l}\text { Brunet-Lezine } \\
\text { Griffiths }\end{array}$ & $\begin{array}{l}99 \\
64\end{array}$ & $\begin{array}{l}\text { NS } \\
\text { NS }\end{array}$ \\
\hline 1 & $\begin{array}{l}\text { Brunet-Lezine } \\
\text { Griffiths } \\
\text { Bailey }\end{array}$ & $\begin{array}{r}253 \\
152 \\
26\end{array}$ & $\begin{array}{l}\text { NS } \\
<0.05 \\
\text { NS }\end{array}$ \\
\hline $11 / 2$ & $\begin{array}{l}\text { Brunet-Lezine } \\
\text { Griffiths }\end{array}$ & $\begin{array}{l}75 \\
70\end{array}$ & $\begin{array}{l}<0.005 \\
<0.01\end{array}$ \\
\hline 2 & $\begin{array}{l}\text { Brunet-Lezine } \\
\text { Griffiths } \\
\text { Bailey }\end{array}$ & $\begin{array}{r}162 \\
95 \\
118\end{array}$ & $\begin{array}{l}<0.01 \\
<0.01 \\
<0.001\end{array}$ \\
\hline 3 & $\begin{array}{l}\text { Griffiths } \\
\text { Stanford-Binet }\end{array}$ & $\begin{array}{l}66 \\
30\end{array}$ & $\begin{array}{l}<0 \cdot 01 \\
\text { NS }\end{array}$ \\
\hline 4 & $\begin{array}{l}\text { Griffiths } \\
\text { Terman-Merrill } \\
\text { Snijders-Oomen }\end{array}$ & $\begin{array}{l}42 \\
26 \\
31\end{array}$ & $\begin{array}{l}\text { NS } \\
<0 \cdot 005 \\
<0 \cdot 025\end{array}$ \\
\hline 5 & Griffiths & 16 & $<0.05$ \\
\hline
\end{tabular}

*Test groups with $\mathrm{n}<4$ were excluded. hypothyroidism that may influence mental development we have studied aetiology and delay in starting treatment. We found that athyroid children had lower IQ and DQ scores than those with ectopic thyroid glands in 19 of 21 test groups. Table 4, however, shows that these differences were significant in only five groups. Hence, the aetiology of hypothyroidism seems to play a minor part in mental development.

In many of the athyroid infants treatment was started relatively late. It seems that the length of time for which they were completely deprived of thyroid hormones after birth was the predominant factor. We tested this assumption by correlating the age at the start of treatment with the results of developmental testing. To exclude the influence of other factors this analysis was carried out in athyroid infants without perinatal risks or associated findings. Fig 2 shows this correlation in athyroid infants at the age of 1 year, the only age group large enough for statistical analysis. As these 116 children were tested in different centres and by different test methods absolute figures could not be used for this evaluation. Individual results were therefore expressed in terms of the standard deviation score devised from the mean and SD of each child's own test group. Fig 2 shows that there was a significant negative correlation between mental development and the age at the start of treatment. DQ scores of infants for whom thyroid substitution had been started during the first month of age showed a more or less 
Table 4 Influence of aetiology on mental development analysed by difference in $D Q$ or IQ scores between patients with athyroidism and those with ectopic thyroid glands

\begin{tabular}{|c|c|c|c|c|c|c|c|}
\hline $\begin{array}{l}\text { Age } \\
\text { (years) }\end{array}$ & Test method & $\begin{array}{l}\text { No } \\
\text { tested }\end{array}$ & $\begin{array}{l}\text { Difference in } \\
D Q(p \text { value })\end{array}$ & $\begin{array}{l}\text { Age } \\
\text { (years) }\end{array}$ & Test method & $\begin{array}{l}\text { No } \\
\text { tested }\end{array}$ & $\begin{array}{l}\text { Difference in } \\
I Q(p \text { value })\end{array}$ \\
\hline 6 months & $\begin{array}{l}\text { Brunet-Lezine } \\
\text { Griffiths }\end{array}$ & $\begin{array}{l}99 \\
64\end{array}$ & $\begin{array}{r}<0.001 \\
0.023\end{array}$ & 3 & $\begin{array}{l}\text { Griffiths } \\
\text { Stanford-Binet }\end{array}$ & $\begin{array}{l}66 \\
30\end{array}$ & $\begin{array}{l}\text { NS } \\
\text { NS }\end{array}$ \\
\hline 1 & $\begin{array}{l}\text { Brunet-Lezine } \\
\text { Griffiths } \\
\text { Bailey } \\
\text { Gesell }\end{array}$ & $\begin{array}{r}253 \\
152 \\
26 \\
7\end{array}$ & $\begin{array}{l}<0 \cdot 001 \\
\text { NS } \\
\text { NS } \\
\text { NS }\end{array}$ & 4 & $\begin{array}{l}\text { Griffiths } \\
\text { Terman-Merrill } \\
\text { Snijders-Oomen }\end{array}$ & $\begin{array}{l}42 \\
26 \\
31\end{array}$ & $\begin{array}{l}\text { NS } \\
\text { NS } \\
\text { NS }\end{array}$ \\
\hline $11 / 2$ & $\begin{array}{l}\text { Brunet-Lezine } \\
\text { Griffiths } \\
\text { Bailey }\end{array}$ & $\begin{array}{l}75 \\
70 \\
19\end{array}$ & $\begin{array}{l}0 \cdot 046 \\
\text { NS } \\
\text { NS }\end{array}$ & 5 & $\begin{array}{l}\text { Griffiths } \\
\text { WPPSI }\end{array}$ & $\begin{array}{l}16 \\
23\end{array}$ & $\begin{array}{l}\text { NS } \\
\text { NS }\end{array}$ \\
\hline 2 & $\begin{array}{l}\text { Brunet-Lezine } \\
\text { Griffiths } \\
\text { Bailey }\end{array}$ & $\begin{array}{r}162 \\
95 \\
118\end{array}$ & $\begin{array}{l}<0 \cdot 001 \\
\text { NS } \\
\text { NS }\end{array}$ & $\begin{array}{l}6 \\
7\end{array}$ & $\begin{array}{l}\text { WISC } \\
\text { HAWIVA }\end{array}$ & $\begin{array}{l}14 \\
13\end{array}$ & $\begin{array}{l}\text { NS } \\
\text { NS }\end{array}$ \\
\hline
\end{tabular}

normal distribution, whereas DQ scores of children treated later than 50 days of age were all below the normal mean. These results underline the importance of starting thyroid replacement treatment as early as possible.

\section{Conclusion}

The aim of neonatal thyroid screening is to prevent mental retardation by diagnosing hypothyroidism early and starting thyroid replacement treatment as soon as possible. With fairly simple and inexpensive means it should be possible to shift the distribution curves of DQ and IQ that were found in hypothy- roid patients before screening started towards those of healthy children (fig 3). The results of our collaborative study show that we are approaching this aim. This study also shows that risk factors and other diseases may also have a considerable influence on mental development and should not therefore be neglected in such an investigation.

In response to our inquiry in 1985 we received detailed data on the mental development of nearly 1000 individual patients with congenital hypothyroidism, which represents about $14 \%$ of all children with congenital hypothyroidism detected in Europe since the introduction of neonatal thyroid screening.

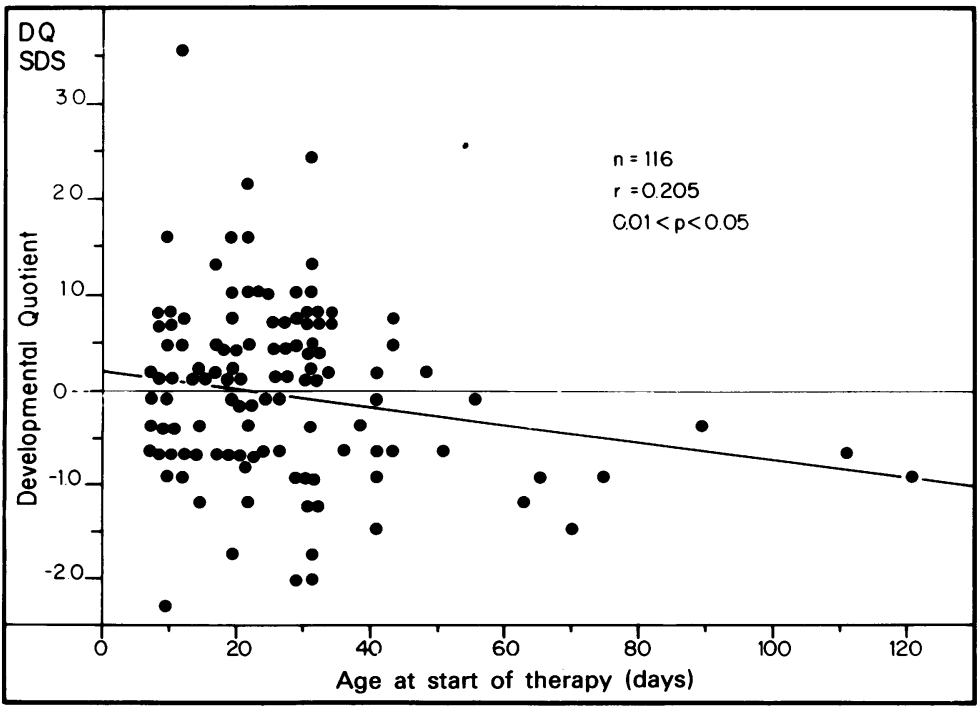

Fig 2 Influence of age at start of treatment on mental development: correlation tested in athyroid infants without risk factors or associated findings at age of 1 year. 


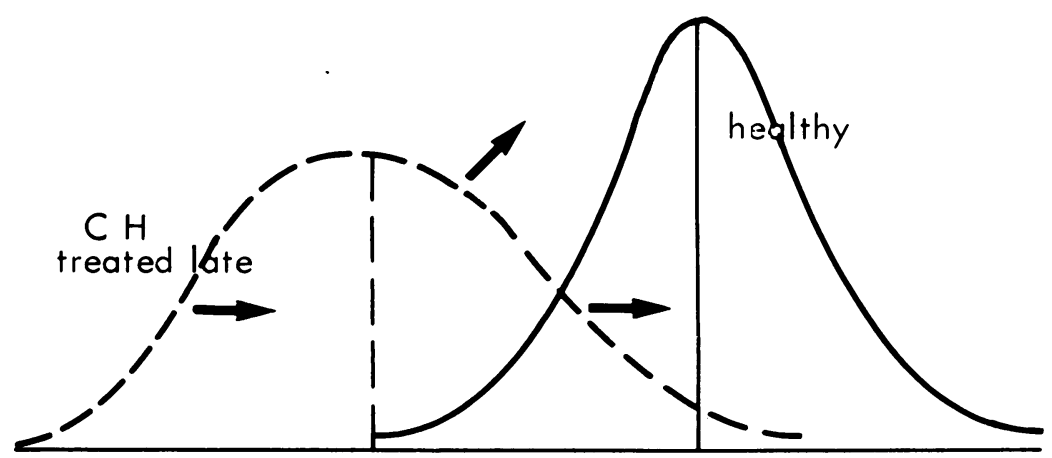

Fig 3 Distribution of $D Q$ and $I Q$ scores in children with congenital hypothyroidism before introduction of neonatal thyroid screening (left) and in healthy children (right); arrows indicate shift of mental outcome towards normal.

Table 5 Progress report: neonatal thyroid screening in Europe based on inquiries of ESPE working group on congenital hypothyroidism

\begin{tabular}{lllcl}
\hline Year & $\begin{array}{l}\text { No of infants } \\
\text { screened }\end{array}$ & $\begin{array}{l}\text { Increase } \\
\text { per year }\end{array}$ & $\begin{array}{l}\text { No of cases } \\
\text { detected }\end{array}$ & $\begin{array}{l}\text { Incidence of } \\
\text { congenital } \\
\text { hypothyroidism }\end{array}$ \\
\hline 1979 & 150180 & +1033320 & 429 & $1: 3500$ \\
1980 & 2534500 & +750100 & 744 & $1: 3400$ \\
1981 & 3284600 & +468670 & 951 & $1: 3500$ \\
1982 & 3753270 & +269841 & 1064 & $1: 3150$ \\
1983 & 3923111 & $+244385 \ddagger$ & 1250 & $1: 3450$ \\
1984 & $+411880 \dagger$ & & $1273 \dagger$ & $1: 3800$ \\
1985 & $24749183 \dagger$ & & $6518 \dagger$ & \\
\hline $1975-85$ & 445 & & \\
\hline
\end{tabular}

*No separate data collection from 1975 to 1978 and in 1984; †total No recorded in February 1986; $\ddagger$ mean increase.

This shows that in many screening centres many children have not only been diagnosed and treated but also followed up carefully.

\section{Progress report}

Table 5 shows the results of the latest inquiry in January-February 1986. During 1985, 4400000 newborn infants were screened in Europe and 1273 children with congenital hypothyroidism were diagnosed. Since 1975, the beginning of neonatal thyroid screening in Europe, nearly 25000000 infants have been tested and 6500 children with congenital hypothyroidism have been diagnosed, an incidence of one in about 3800 newborn children. After an early rapid increase in the number of infants being screened each year the rate is now stabilising as screening programmes have been widely introduced. National screening programmes covering over $90 \%$ of neonates have been introduced in Austria, Belgium, Denmark, Finland, France, Federal Republic of Germany, Grecce, Hungary, Iceland, Ireland, Israel, Luxembourg, The Netherlands, Norway, Spain, Sweden, Switzerland, and the
United Kingdom; programmes covering $50-75 \%$ of neonates have been introduced in Czechoslovakia, Italy, Portugal, and Yugoslavia; and programmes covering $10-20 \%$ of neonates have been introduced in the Democratic Republic of Germany and Poland. This is indeed a great success considering that neonatal thyroid screening was first introduced only 10 years ago.

Data on mental development in children with congenital hypothyroidism were obtained from the following physicians and psychologists (listed in alphabetical order according to countries and cities): Belgium: $\mathbf{M}$ Verboven (Brussels), $\mathbf{R}$ Wolter (Brussels), $\mathbf{M}$ Vanderschueren-Lodeweyckx (Leuven), JP Bourguignon (Liège), P Malvaux (Louvain). Denmark: B Brock-Jacobsen (Roskilde/ Copenhagen). England: DB Grant (London). Federal Republic of Germany: A Grueters (Berlin), M Klett (Heidelberg). Finland: M Virtanen (Helsinki). France: JP Farriaux (Lille), M David (Lyon), JE Toublanc (Paris), P Rochiccioli (Toulouse). Greece: S Pantelakis (Athens). Israel: J Sack (Tel Hashomer). Italy: E Cacciari (Bologna), C Romano (Genova), G Chiumello (Milan), G Giovannelli, C Volta (Parma), L Moschini (Rome), GC Mussa (Turin), D Gaburro (Verona). Netherlands: A Kalverboer (Groningen). Norway: S Heyerdahl (Oslo). Scotland: HJ Jackson (Glasgow). Sweden: A Ilicki, A Larsson (Uppsala). Switzerland: K Zuppinger (Berne), P Sizonenko (Geneva), R Illig (Zurich).

This study was carried out on behalf of the European Society for 
Paediatric Endocrinology and was supported by Nordisk Gentofte A/S Denmark and the Swiss National Science Foundation Grant No 3.906 .083 .

\section{References}

1 Andersen $\mathrm{H}$. The aspects of mental retardation in hypothyroidism. Proceedings of the second international congress on mental retardation, Vienna, 1961, part I. Basle: Karger, 1963:311-6.

2 Rochiccioli P, Dutau G, Bayard F, Augier D. Neonatal detection of hypothyroidism by radioimmunoassay of thyroxine in the eluate of dried blood. Pediatr Res 1975;9:685.

${ }^{3}$ Illig R, Torresani T, Sobradillo B, Scherz R. Detection of neonatal hypothyroidism in Switzerland by TSH determination using filter paper blood samples. Pediatr Res 1978;12:154.

${ }^{4}$ Sack J, Amado O, Frucht H, Lunenfeld B. Screening for neonatal hypothyroidism using both T4 and TSH spot assay. Pediatr Res 1978;12:1085.

${ }^{5}$ Brock Jacobsen B, Brandt NJ, Hummer L, Munkner T, Soren- sen TS. Clinical and hormonal findings in cases of congenital hypothyroidism discovered by neonatal screening. Pediatr Res 1979:13:1190.

6 Rochiccioli P, Dutau G, Augier D, Enjaume P. Report on a mass screening program (14000 samples) for neonatal hypothyroidism using a filter paper T4 and TSH method. Pediatr Res 1978;12:154

7 Larsson A, Bodegard G, Ekman K, Ljunggren JG, Nilsson A. Olin P. Screening for congenital hypothyroidism-results from a pilot study in Stockholm. Pediatr Res 1979;13:1189.

${ }^{8}$ Rochiccioli P, Dutau G, Augier D, Enjaume C. Neonatal screening for hypothyroidism by simultaneous determination of T4 and TSH on filter paper. Pediatr Res 1979;13:1189.

${ }^{9}$ Illig R, Largo R. European collaborative study on mental development in children with congenital hypothyroidism diagnosed by neonatal thyroid screening. Pediatr Res 1985;19:615.

Correspondence and requests for reprints to Dr R Illig, Kinderspital, Steinwiesstrasse 75, CH-8032 Zurich, Switzerland 